\title{
Botanical Extracts of the Brazilian Savannah Affect Feeding and Oviposition of Plutella xylostella (Linnaeus, 1758) (Lepidoptera: Plutellidae)
}

\author{
Irys Fernanda Santana Couto ${ }^{1}$, Sandra Verza da Silva ${ }^{1,2}$, Fabricio Iglesias Valente ${ }^{1}$, Bruno Sena de Araújo ${ }^{3}$, \\ Silvana Aparecida de Souza ${ }^{1}$, Munir Mauad ${ }^{4}$, Silvana de Paula Quintão Scalon ${ }^{4} \&$ Rosilda Mara Mussury ${ }^{1}$ \\ ${ }^{1}$ Laboratory of Insect-Plant Interaction, Faculty of Biological and Environmental Sciences, Federal University \\ of Grande Dourados, Dourados, MS, Brazil \\ ${ }^{2}$ Laboratory of Social Insects-Pest, Department of Vegetal Production, Phytosanitary Defense, Faculty of \\ Agronomic Sciences, São Paulo State University, Botucatu, São Paulo, Brazil \\ ${ }^{3}$ Faculty of Biological Sciences and Health, Centro University of Grande Dourados, Dourados, MS, Brazil \\ ${ }^{4}$ Laboratory of Vegetables Production, Faculty of Agricultural Sciences, Federal University of Grande Dourados, \\ Dourados, MS, Brazil \\ Correspondence: Sandra Verza da Silva, Laboratory of Insect-Plant Interaction, Faculty of Biological and \\ Environmental Sciences, Federal University of Grande Dourados, Highway Dourados, Itahum, km 12, Dourados, \\ MS, Brazil. E-mail: sandraverza@yahoo.com \\ Rosilda Mara Mussury, Laboratory of Insect-Plant Interaction, Faculty of Biological and Environmental \\ Sciences, Federal University of Grande Dourados, Highway Dourados, Itahum, km 12, Dourados, MS, Brazil. \\ E-mail: mussuryufgd@gmail.com
}
Received: September 16, 2018
Accepted: February 11, 2019
Online Published: April 15, 2019
doi:10.5539/jas.v11n5p322
URL: https://doi.org/10.5539/jas.v11n5p322

\begin{abstract}
The indiscriminate use of synthetic insecticides caused an increase in the resistance of Plutella xylostella (Linnaeus, 1758) (Lepidoptera: Plutellidae) to almost all classes of insecticides, as well as affected the environment and non-target organisms. Thus, the search for less harmful alternatives with the purpose of reducing the application of these insecticides has become a priority. A possible alternative to reduce the use of synthetic insecticides is by using botanical insecticides, given the thousands of existing compounds derived from secondary metabolism in plants. In this study, we tested the following hypotheses: (i) the aqueous and ethanolic extracts of native plants reduce the food consumption of larvae and oviposition of adults of P. xylostella; (ii) these botanical species can act as potential plant insecticides. The objective of this work was to evaluate the effect of plant extracts on the feeding preference of larvae and oviposition of adults of P. xylostella. For this, cabbage discs treated with aqueous and ethanolic extracts of Schinus terebinthifolius, Annona coriacea, Annona crassiflora and Serjania marginata were given to larvae. The concentrations used for the aqueous extracts were of 5 and $10 \mathrm{mg} \mathrm{mL}^{-1}$, and for the ethanolic extracts were of 1 and $5 \mathrm{mg} \mathrm{mL}^{-1}$. Both extracts of the four tested plant species showed oviposition suppressed. The extract of $S$. marginata showed the lowest rates of suppression. All treatments with ethanolic extracts showed a phagodeterrant effect being that the aqueous and ethanolic extracts of $A$. crassiflora and $S$. terebinthifolius were the most effective as antifeedants on third instar larvae by $P$. xylostella.
\end{abstract}

Keywords: Diamondback moth, food preference, phagodeterrence, Schinus terebinthifolius, Annona spp., Serjania marginata

\section{Introduction}

Brassicaceae is one of the most important botanical families in the world economy (Vickers et al., 2004). In Brazil, the members of this family are important in most of the national territory, being cultivated both in family farming and by large producers of vegetables (Aragão et al., 2008). However, considerable losses in production occur because of pest attacks, of which Plutella xylostella (Linneaus, 1758) (Lepidoptera: Plutellidae), popularly known as the diamondback moth, stands out as the most important (Li et al., 2016). As a consequence of the high 
selection pressure due to the indiscriminate use of insecticides, and the high genetic elasticity inherent in the species, P. xylostella has developed resistance to almost all classes of insecticides, making it difficult to control (Khaliq et al., 2007; Li et al., 2016; Mohan \& Gujar, 2003; Sarfraz \& Keddie, 2005).

The increase in resistant populations and environmental hazards has forced us to continually search for new ways to protect the crop. One possible way to reduce the use of synthetic insecticides is by using botanical insecticides (Dayan et al., 2009; Lestari et al., 2015; Pavela, 2004; Peres et al., 2017). Botanic insecticides are selective for vertebrates and do not persist in the environment (Isman, 1994) and can be easily produced by farmers and small industries (Talukder \& Howse, 1994). According to Prakash and Rao (1997), these botanical insecticides do not contribute to the increase in resistance and pest resurgence; they do not have negative effects to natural enemies (Isman, 1994), and thus, plants could be the best source of new chemical structures for the development of new environmentally correct and safe insect control agents (Saxena et al., 1992).

A study by Couto et al. (2016) evaluating the aqueous and methanolic extracts of the leaves of Annona coriacea Mart. and Schinus terebinthifolius Raddi.showed that these plants negatively affected the feeding of P. xylostella, reducing the leaf consumption of third instar larvae (caterpillars).

There are several plant families with the potential to be used for insect control (Camaroti et al., 2018), such as, Annonaceae (Ribeiro et al., 2018), Sapindaceae (Castillo et al., 2009), Meliaceae (Sapindal et al., 2017) and Rubiaceae (Peres et al., 2017). Highlighted among the substances useful for insect control are those with insecticidal action (Amoabeng et al., 2014), oviposition inhibitors (Torres et al., 2006), growth regulators (Koul, 2012), repellents (Koul, 2008), or those that only distance insects from the plants such as feeding inhibitors (Couto et al., 2016; Koul, 2005, 2008).

A decrease in oviposition and food consumption in insects indicates a future population reduction. Hence, knowledge of the mode of action of plant extracts allows bioactive substances from plants to be more efficiently used. According to Shin-Foon and Yu-Tong (1993), this makes them compatible with the intent of integrated pest management (IPM) programs, especially for crucifers whose economic value and lack period restrict the use of synthetic insecticides.

In some situations (for protection of the crop), it may be more appropriate to use substances that only discourage the action of herbivores, since the elimination of some insects can cause ecological imbalance; in addition, such substances limit the development potential of the insect-pest. The advantage of this is its selective action against parasites and pest predators, as well as pollinators. Plant antifeedant substances prepared from secondary metabolites are found in all groups; however, the most effective insect feeding inhibitors come from terpenoids, alkaloids, saponins, and polyphenols (Koul, 2005) and oviposition reducers come from cumarina and rutina (Tabashnik, 1985) andrographolide (Hermawan et al., 1998) and a-terpineno, Limonene, linalool (Zhang et al., 2004), essential oils (Dover, 1985; Zhang et al., 2004) and plant extracts (Abbasipour et al., 2010; Basukriadi \& Wilkins, 2014; Chen et al., 1996; Egigu et al., 2010; Kodjo et al., 2011; Medeiros et al., 2005; Patil et al., 2003). These substances also inhibit the oviposition of P. xylostella.

As the extract of a particular plant may contain thousands of compounds, derived from secondary metabolism, in this study, we tested the following hypotheses: (i) aqueous and ethanolic extracts of native plants reduce the feeding and oviposition of P. xylostella; (ii) these botanical species can act as potential plant insecticides. The present study analyzed the effect of aqueous and ethanolic extracts of Schinus terebinthifolius Raddi (Anacardiaceae), Annona coriacea Mart. (Annonaceae), Annona crassiflora Mart. (Annonaceae), and Serjania marginata Casar (Sapindaceae) (which occur in the state of Mato Grosso do Sul, Brazil) on the feeding preference of larvae and oviposition of adults of $P$. xylostella.

\section{Materials and Methods}

\subsection{Development of Plutella xylostella}

The larvae and pupae of $P$. xylostella were collected from cabbage plantation areas in the cities of Dourados $\left(22^{\circ} 13^{\prime} 16^{\prime \prime} \mathrm{S} ; 54^{\circ} 48^{\prime} 20^{\prime \prime} \mathrm{W}\right)$ in the state of Mato Grosso do Sul. The collected P. xylostella were reared at the Insect-Plant Interaction Laboratory of the Faculty of Biological and Environmental Sciences at the Federal University of Grande Dourados (UFGD), Mato Grosso do Sul, Brazil. Individuals were maintained under laboratory conditions of $25 \pm 2{ }^{\circ} \mathrm{C}, 12$ hours of photoperiod, and relative humidity of $55 \pm 5 \%$. The pupae were placed in transparent plastic cages until the adults emerged. Adults were fed with a $10 \%$ honey solution and were provided with an oviposition substrate of cabbage discs measuring $8 \mathrm{~cm}$ in diameter placed on moist filter paper.

After oviposition, the leaves holding the eggs were placed in sterile plastic containers measuring $30 \mathrm{~cm}$ in length, $15 \mathrm{~cm}$ in width, and $12 \mathrm{~cm}$ in height. Once hatched, the larvae remained in this container until reaching the pupal 
stage. The larvae were fed on leaves of organic cabbage (Brassica oleracea var. acephala DC) that were first treated with $5 \%$ sodium hypochlorite solution and then washed in tap water.

Young cabbage leaves, located in the third and fourth node, were collected from plants that had 90 days of growth in the organic garden of the UFGD. Healthy cabbage leaves were placed with the adaxial face against the plastic container. The larvae were placed on the abaxial face, and then covered with another cabbage leaf that was oriented with the abaxial face covering them. This procedure was repeated daily or when the leaves were wilted, whichever occurred first, and continued until pupae formation (Barros et al., 2012). For the experiments carried out in this work were used individuals of the first generation obtained from the laboratory creation.

\subsection{Botanical Material}

Healthy and fully expanded leaves of S. terebinthifolius, S. marginata, A. coriacea, and A. crassiflora were collected from the garden of medicinal plants at the Federal University of Grande Dourados and from the farms Coqueiro (forest) and Santa Madalena (Cerrado) in the city of Dourados-MS (22 $14^{\prime} \mathrm{S}$, longitude $54^{\circ} 9^{\prime} \mathrm{W}$ and altitude $452 \mathrm{~m}$ ), between $7 \mathrm{am}$ and $9 \mathrm{am}$, between March and May of 2012. Authorization for collection of botanical material was granted by the Brazilian National Research Council (CNPq)/Council of Genetic Heritage Management (CGEN/MMA, number 010220/2015-1).

The plant species were identified by a specialist from the laboratory of Applied Botany, and exsiccated samples were deposited at the Herbarium of the Federal University of Grande Dourados, Mato Grosso do Sul, Brazil, with the following registration numbers: Annona coriacea: DDMS 5419, Annona crassiflora: DDMS 5499, Schinus terebinthifolius: DDMS 5688, and Serjania marginata: DDMS 5561.

\subsection{Preparation of Aqueous and Ethanolic Extracts}

The leaves were dried in a forced circulation oven for three days at a maximum temperature of $\left(40 \pm 1^{\circ} \mathrm{C}\right)$. After this period, the dried leaves were crushed until a fine powder was obtained.

The maceration technique was used to prepare the aqueous extract (AE), in which $10 \mathrm{~g}$ or $5 \mathrm{~g}$ of vegetable matter (leaf powder) were dissolved in $100 \mathrm{~mL}$ of distilled water and after manual shaking, they were allowed to rest for 24 hours in a refrigerated place in order to extract the hydrosoluble compounds. Which were then strained through a voile fabric to obtain the $\mathrm{AE}$ solutions at concentrations of $10 \%$ and $5 \%$.

To prepare the ethanolic extract (EE), samples of $100 \mathrm{~g}$ of the powder were placed in a beaker along with $1000 \mathrm{~mL}$ of solvent (ethanol). Filtrations were performed every 2 days for 15 days. The filtered extract was concentrated in a rotary evaporator at $60^{\circ} \mathrm{C}$ under reduced pressure. The product obtained in this process was dissolved in distilled water at concentrations of $1 \mathrm{mg} \mathrm{mL}^{-1}$ and $5 \mathrm{mg} \mathrm{mL}^{-1}$ for subsequent tests.

\subsection{Test with Aqueous and Ethanolic Extracts on the Feeding of P. xylostella}

The free choice tests occurred in an environment at $25 \pm 1{ }^{\circ} \mathrm{C}, 55 \pm 5 \% \mathrm{RH}$ and photoperiod of 12 hours. The cabbage discs ( $4 \mathrm{~cm}$ in diameter) were placed in a Petri dish cross-shaped distributions and equidistantly (Figure 1), two of them immersed in extract and the others immersed in distilled water. Three larvae of third instar of $P$. xylostella were placed on each plate. The instar was identified by the width of the cephalic capsule of the larvae $(0.33-0.44 \mathrm{~mm})$. After 24 hours, the insects were removed and the leaf area was scanned, and the images measured using the software ImageJ (Schneider et al., 2012). The leaf consumption was obtained by the difference between the initial area of the leaf and the area that remained after larval feeding.

\subsection{Test With Aqueous and Ethanolic Extracts on the Oviposition of P. xylostella}

Three adult pairs (one male and one female) of P.xylostella of up to $12 \mathrm{~h}$ of age were introduced into the cages and kept there for four days for oviposition. They were fed a $10 \%$ honey solution. Egg counting and disk exchange were performed daily for a period of 4 days. The same experimental procedure was performed for the ethanolic extracts. The experiment was kept in laboratory in the following conditions: temperature of $25 \pm 1{ }^{\circ} \mathrm{C}$, relative humidity of $55 \pm 5 \%$, and $12 \mathrm{~h}$ photoperiod. 

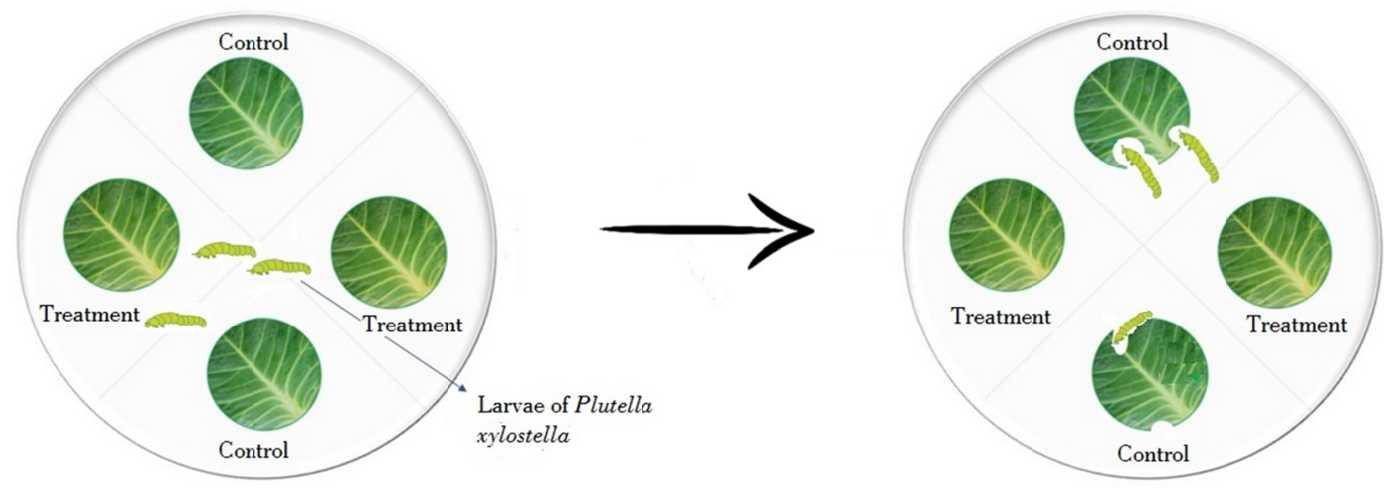

Figure 1. Schematic representation of the food preference test of Plutella xylostella larvae

\subsection{Analysis of the Data}

\subsubsection{Food Preference}

The experiment was conducted in a completely randomized design in a factorial scheme with the aqueous extract ( 4 plants $\times 2$ concentrations) and the ethanolic extract (4 plants $\times 2$ concentrations), both with 5 replicates, with each replicate consisting of 10 subsamples. The data were submitted to normality test Lilliefors (Gross \& Ligges, 2012) and, when they were presented normal was performed variance analysis and the compare means by Tukey test at $5 \%$ probability ASSISTAT (Silva \& Azevedo, 2016).

\subsubsection{Oviposition Suppression Index}

The experiment was conducted in a completely randomized design in a factorial scheme with the aqueous extract ( 4 plants $\times 2$ concentrations + water) and the ethanolic extract $(4$ plants $\times 2$ concentrations + water), both with 10 replicates. The data were submitted to normality test Lilliefors (Gross \& Ligges, 2012) and, when they were presented normal was performed variance analysis and the means were compared by the Tukey test at $5 \%$ probability ASSISTAT (Silva \& Azevedo, 2016).

\subsubsection{Calculation of Food Preference Index (PI)}

Observation on after $24 \mathrm{~h}$ were recorded and subjected to analysis of food preference (Medeiros \& Boiça Júnior, 2005; Feng et al., 2012; Boiça Júnior et al., 2013; Negi et al., 2016). The effect produced by the plant extract was evaluated using the food preference index (Kogan \& Goeden, 1970), and they were classified as phagostimulant if the index was greater than 1 , neutral if equal to 1 , and phagodeterrant if less than 1 , using the formula:

$$
\mathrm{PI}=2 \mathrm{~A} /(\mathrm{M}+\mathrm{A})
$$

where, $\mathrm{A}=$ area consumed of treated discs; $\mathrm{M}$ = consumed areas of untreated discs.

\subsubsection{Calculation of Oviposition Suppression Index (ISO)}

The effect produced by the plant extract was evaluated using the oviposition suppression index (Kogan \& Goeden, 1970):

$$
\mathrm{ISO}=2 \mathrm{~A} /(\mathrm{M}+\mathrm{A})
$$

where, $\mathrm{A}=$ amount of eggs in leaves treated with extract and $\mathrm{M}=$ quantity of eggs in the leaf treated with water. ISO values range from zero to two, being classified as favored oviposition if the index is greater than 1, neutral if equal to 1 and oviposition suppressed if smaller than 1 .

\section{Results}

\subsection{Food Preference}

The aqueous extract showed an interaction between treatments, plant extracts, and concentration $(\mathrm{F}=11.80$; DF $=3 ; \mathrm{P} \leq 0.01$ ).

No difference was observed in treatments of aqueous extracts at a concentration of 5\%; however, the treatment with S. marginata extract showed a higher food preference index at a concentration of $10 \%$, thus stimulating the feeding of the larvae. On the other hand, the other extracts reduced leaf consumption. Although the IP of $S$. marginata $(10 \%)$ presented a higher value than the others $(\mathrm{IP}=1.33)$, it was observed in vivo that the larvae showed a reduction in mobility (Figure 2A). 
The lowest food preference index was observed in the $A$. crassiflora $10 \%$ treatment (IP $=0.59$ ), followed by $S$. terebinthifolius $10 \%$ (IP $=0.61)$. The lowest leaf consumption for the aqueous extract of all treatments was observed in the S. terebinthifolius 10\% treatment (Figure 2A).

Treatments with $A$. crassiflora and $S$. terebinthifolius were phagodeterrants in all treatments, whereas $A$. coriacea was phagodeterrant at a concentration of $10 \%$ only (Figure 2A).

With the ethanolic extracts, there was no interaction between the factors (plant extracts and concentration) $(\mathrm{F}=$ $0.1729 ; \mathrm{DF}=3 ; \mathrm{P} \geq 0.05)$, as it was only significant in the concentration factor $(\mathrm{F}=21.87 ; \mathrm{DF}=1 ; \mathrm{P} \leq 0.01)$. The mean value of the preference index for the concentration of $1 \mathrm{mg} \mathrm{mL}^{-1}$ was 0.84 and for the concentration of $5 \mathrm{mg} \mathrm{mL}^{-1}$ was 0.61 .

It was observed that all disks treated with ethanolic extracts presented a phagodeterrant effect, and that the preference index decreased with an increase in concentration (Table 2). The ethanolic extract of $S$. terebinthifolius had the lowest preference indexes $(0.73$ and 0.55$)$ at both concentrations $\left(1 \mathrm{mg} \mathrm{mL}^{-1}\right.$ and $5 \mathrm{mg}$ $\mathrm{mL}^{-1}$, respectively) (Figure 2B).

All of the extracts reduced leaf consumption at a concentration of $5 \mathrm{mg} / \mathrm{mL}$, especially those from plants belonging to the genus Annona (Figure 2B).
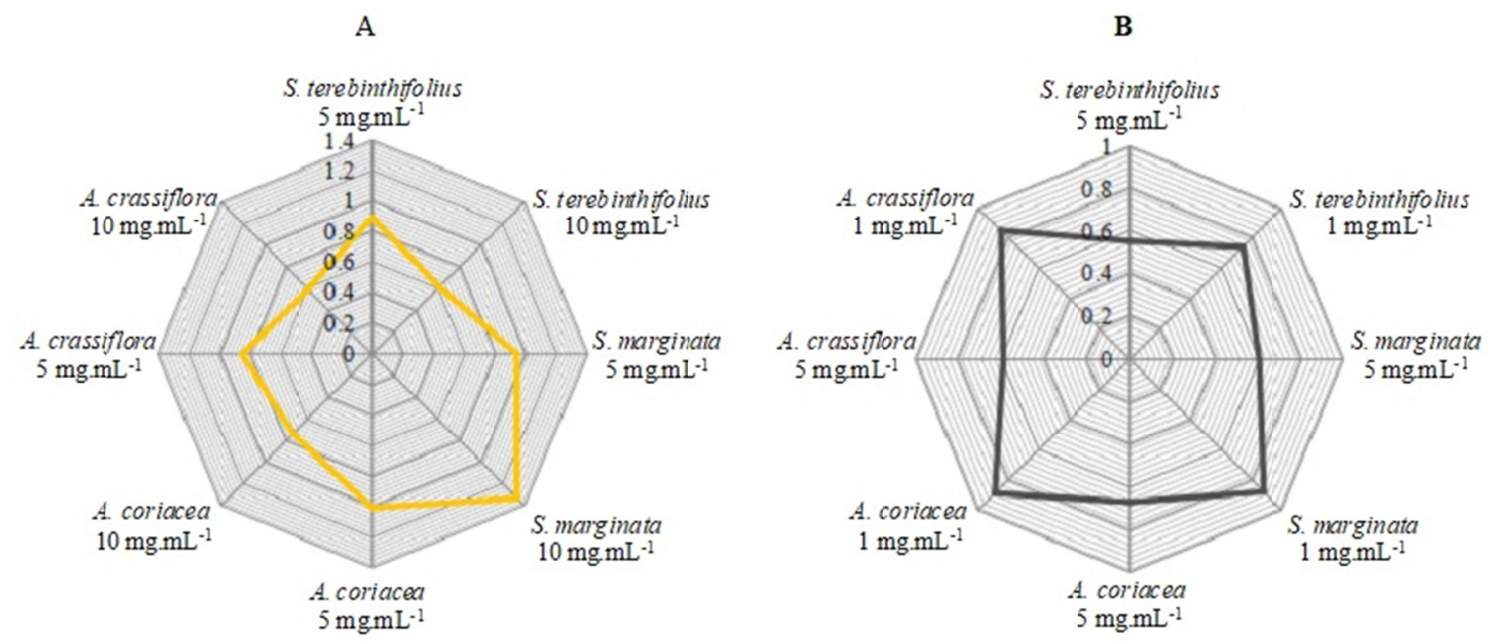

Figure 2. Mean values of the preference index of Plutella xylostella for cabbage discs treated with aqueous extract (A) and ethanolic extract (B) at different concentrations

\subsection{Oviposition}

The aqueous extract $(\mathrm{F}=11.01 ; \mathrm{GL}=4 ; \mathrm{P}=0.00001)$ and ethanolic extract $(\mathrm{F}=24.77 ; \mathrm{GL}=4 ; \mathrm{P}=0.00001)$ showed an interaction between treatments, plant extracts, and concentration.

The aqueous and ethanolic extracts of the four plants species tested differed significantly from the control for both concentrations. Females preferentially oviposited in the leaves containing water. The leaves treated with aqueous extract of $S$. marginata contained a smaller amount of eggs, followed respectively by $A$. crassiflora, $S$. terebinthifolius and A. coriaceae (Table 1).

In relation to the ethanolic extract, $S$. marginata presented the least amount of eggs deposited by treated leaves, followed by S. terebinthifolius. Plants of the genus Annona did not differ statistically from each other (Table 2).

In all the aqueous and ethanolic extracts tested, it was observed that the oviposition suppression index presented results lower than 1. Thus, oviposition was suppressed in all treatments, being for $S$. marginata the lowest results observed in both extracts and concentrations were observed (Tables 1 and 2).

It was also observed that there was a reduction in the number of eggs when the concentration of the extracts was increased. The lowest indexes of oviposition suppression were observed at the highest concentrations of each treatment (Tables 1 and 2). 
Table 1. Index of oviposition suppression (IOS) and egg mean by treatment of aqueous extract

\begin{tabular}{lllll}
\hline Treatment & & Number of eggs (average) & IOS & Classification \\
\hline $5 \mathrm{mg} \mathrm{mL}{ }^{-1}$ & Control & $290.5 \pm 2.41 \mathrm{a}^{*}$ & - & - \\
& S. terebinthifolius & $185.2 \pm 1.86 \mathrm{bc}$ & 0.78 & Oviposition suppressed \\
& S. marginata & $83.7 \pm 1.10 \mathrm{f}$ & 0.45 & Oviposition suppressed \\
& A. coriacea & $188.8 \pm 1.56 \mathrm{~b}$ & 0.79 & Oviposition suppressed \\
\hline $10 \mathrm{mg} \mathrm{mL}^{-1}$ & A. crassiflora & $168.8 \pm 2.01 \mathrm{~cd}$ & 0.74 & Oviposition suppressed \\
& S. terebinthifolius & $156.3 \pm 1.72 \mathrm{~d}$ & 0.70 & Oviposition suppressed \\
& S. marginata & $49.9 \pm 0.63 \mathrm{~g}$ & 0.29 & Oviposition suppressed \\
& A coriacea & $159.2 \pm 1.75 \mathrm{~d}$ & 0.71 & Oviposition suppressed \\
$\mathrm{CV}(\%)$ & A crassiflora & $133.2 \pm 1.62 \mathrm{e}$ & 0.63 & Oviposition suppressed \\
\hline
\end{tabular}

Note. *Means followed by the same letter in the column do not differ from each other by the Tukey test at $5 \%$ probability.

Table 2. Index of oviposition suppression (IOS) and egg mean by treatment of ethanolic extract

\begin{tabular}{lllll}
\hline Treatment & & Number of eggs (average) & IOS & Classification \\
\hline $1 \mathrm{mg} \mathrm{mL}{ }^{-1}$ & Control & $357.8 \pm 4.45 \mathrm{a}^{*}$ & - & - \\
& S. terebinthifolius & $176.4 \pm 1.93 \mathrm{~b}$ & 0.66 & Oviposition suppressed \\
& S. marginata & $65.6 \pm 1.21 \mathrm{e}$ & 0.31 & Oviposition suppressed \\
& A. coriacea & $179.4 \pm 1.70 \mathrm{~b}$ & 0.67 & Oviposition suppressed \\
\hline $5 \mathrm{mg} \mathrm{mL}$ & A. crassiflora & $172.8 \pm 2.22 \mathrm{~b}$ & 0.65 & Oviposition suppressed \\
& S. terebinthifolius & $106.2 \pm 1.20 \mathrm{~d}$ & 0.46 & Oviposition suppressed \\
& S. marginata & $24.7 \pm 0.54 \mathrm{f}$ & 0.13 & Oviposition suppressed \\
CV $(\%)$ & A crassiflora & $130.0 \pm 1.79 \mathrm{c}$ & 0.53 & Oviposition suppressed \\
\hline Note. & & $123.8 \pm 1.63 \mathrm{c}$ & 0.51 & Oviposition suppressed \\
\hline
\end{tabular}

Note. *Means followed by the same letter in the column do not differ from each other by the Tukey test at $5 \%$ probability.

\section{Discussion}

Plant compounds can act in several ways, especially in a complex mixture of active molecules that can affect insects. Studies have shown that organic compounds of plants with insecticidal activity can act as inhibitors of insect feeding, and can affect growth, development, reproduction, and diapause (Freitas et al., 2014; Menezes, 2005). In this study, the active substances acted as antifeedants, that is, they inhibited the larvae feeding activity and oviposition suppressants, that is, they inhibited the moth to oviposit.

The results obtained from the food preference tests carried out in this study showed that the aqueous extract of $S$. marginata served as a feeding stimulant for the larvae. On the other hand, the aqueous and ethanolic extracts of $S$. marginata showed the highest indexes of suppressed oviposition. The species of the genus Serjania and their biological properties are little studied. Nevertheless, the scientific literature describes Serjania species to possess different biological properties, such as gastroprotective, antifungal, analgesic, anti-inflammatory, antioxidant, anticancer, and antiprotozoal activities. Phytochemical studies on plants of the genus Serjania reveal the presence of a range of compounds, including saponins, flavonoids, terpenes, steroids, tannins, alkaloids, and fatty acids (Heredia-Vieira et al., 2015).

In the current study, a phagostimulant effect and suppressed oviposition by S. marginata was observed when the concentration was increased; hence, it is assumed with increasing concentration there was an increase in stimulant substances, which may have caused a greater feeding stimulus and reduction in oviposition in leaves treated with the extract in question.

Périco et al. (2015) reported that plants of the Sapindaceae family have saponins and tannins. The high saponin content of Sapindaceae fruits has foam-forming properties and can be used as an insecticide (Fernandes et al., 2007), which may cause an inhibitory effect on P. xylostella oviposition. Saponins are substances mainly related to 
the defense system. The amphiphilic behavior of saponins and their ability to form complexes with steroids, proteins, and phospholipid membranes allow for diverse biological actions (Schenkel et al., 2001).

Tannins are metabolites that act to significantly reduce the growth and survival of many herbivores. They act as repellents to a wide variety of animals; their toxicity is attributed to the ability to form nonspecific proteins in the digestive tract of herbivores, negatively affecting their nutrition (Taiz \& Zeiger, 2013).

Simpson and Simpson (1990) claim that high consumption of certain extracts is not always advantageous to the insects, because an increase in the inhalation of allelochemicals can result in harmful effects on their development. Thus, we can suppose that the food stimulation caused by S. marginata on P. xylostella larvae and the induction to reduce oviposition, could lead to a decrease in the populations of this pest, since it can result in a reduction of the insect population.

The leaf extracts of $S$. terebinthifolius, $A$. coriacea, and $A$. crassiflora were not as effective as the extract of $S$. marginata, but they also showed an oviposition-inhibiting effect. The suppression of oviposition occurred due to the presence of secondary metabolites extracted from these plants.

The oviposition of P. xylostella occurs through olfactory and gustatory stimuli (Ang et al., 2016) through chemoreceptors in the ovipositor, tarsus, or mouth (Feng et al., 2017). The secondary metabolites present in the tested plant extracts act to reduce the oviposition stimuli of moths. Secondary metabolites belonging to the Brassicaceae family that stimulate diamondback moth oviposition, mask the action of glucosinolates and cause irritability in females when they are in contact with treated surfaces (Mordue \& Blackwell, 1993).

Egigu et al. (2010) showed that oviposition by $P$. xylostella moths is significantly reduced when using the methanolic extract of Cordeauxia edulis (Fabaceae), suggesting that this extract also regulates the pest population, protecting the plants against possible damages. Previously Qiu et al. (1998) and Charleston et al. (2006) reported deterrent effects of neem (Azadirachta indica A. Juss.) and syringa berrytree (Melia azedarach L.) extracts on P. xylostella oviposition. There are receptor cells present in the olfactory sensilla of the antennae that are sensitive to inhibitory compounds (Qiu et al., 1998). These receptor cells prevent oviposition by signaling to the moths that the substrate is not suitable for oviposition and development of their offspring.

In this study, the inhibition of oviposition of $P$. xylostella was directly related to the increased concentration of aqueous extracts, independent of the plant species used, demonstrating that the inhibiting effect on oviposition is accentuated by the quantity and type of extracted substances.

In relation to food preference, the aqueous and ethanolic extracts of $A$. crassiflora and $S$. terebinthifolius are more effective as antifood for $P$. xylostella third instar caterpillars.

In a recent study, Krinski et al. (2014) showed the effectiveness of Annona as insecticidal plants for different insects. The secondary metabolites corresponding to the insecticidal activities of Annona belong to the class of acetogenins. These substances inhibit NADH in the mitochondria, provoking mortality in the insects (Zafra-Polo et al., 1996). The bioactivity of acetogenins can vary significantly depending on the plant species as well as the solvent used in the extraction (Chirinos et al., 2007; Shaalan et al., 2005).

Regarding the order Lepidoptera, Freitas et al. (2014) observed the reduction of larval survival in Spodoptera frugiperda (J. E. Smith, 1797) Lepidoptera: Noctuidae) using Annona extracts. Extracts of A. coriacea added to the diet of Anagasta kuehniella (Zeller, 1879) (Lepidoptera: Pyralidae) caused mortality of 50\% of the larvae and acted as antifood (Coelho et al., 2007). Aqueous and methanolic extracts of $A$. coriacea reduced the feeding of $P$. xylostella caterpillars by $50 \%$, thereby being classified as phagodeterrent (Couto et al., 2016).

The effects observed in $S$. terebinthifolius can be explained by the presence of secondary metabolites, including tannins and flavonoids (Johann et al., 2010). Tannins inhibit digestion by deactivating digestive enzymes, creating a tannin-protein complex that is difficult to digest, thereby affecting the growth and survival of insects (Mello \& Silva-Filho, 2002). Procópio et al. (2015) showed that the leaf extract of $S$. terebinthifolius caused damage to the midgut of Aedes aegypti (Linnaeus, 1762) (Diptera: Culicidae) larvae, interfering with survival and development.

Thus, the ethanolic and aqueous extracts of the leaves of $A$. coriaceae, S. terebinthifolius and A. crassiflora acted to reduce feeding of $P$. xylostella larvae; The oviposition preference tests showed that the aqueous and ethanolic extracts of $S$. marginata were more effective as a suppressor of the oviposition of this insect pest.

The literature is abundant on the use of botanical extracts in insect control. Extracts from plants such as Vitex negundo L., significantly reduces $P$. xylostella larvae survival and adult oviposition (Yuan et al. 2006). Extracts from Muntingia calabura L. fruits and flowers also show high toxicity to larvae, pupae and adult P. xylostella, suggesting effective use of these compounds as insecticides for the control of P. xylostella (Neto Bandeira et al. 
2013). Crude methanolic extracts of Trichilia americana (Sessé \& Moc.) T.D. Penn.and ethanolic extracts of Annona squamosa L. seeds reduced pupal weight and exhibited toxic activity against the Spodoptera litura (Fabr 1775) (Lepidoptera: Noctuidae) (Wheeler et al., 2001; Wheeler \& Isman, 2001). Ethanolic seed extracts of $A$. squamosa and A. muricata L. reduced larval growth of S. litura and the cabbage looper, Trichoplusia ni (Hbn., 1803) (Lepidoptera: Noctuidae) (Leatemia \& Isman 2004), while acetonic seed extracts of A. squamosa showed insecticidal activity against the cabbage head caterpillar, Crocidolomia binotalis Zeller, 1852 (Lepidoptera: Crambidae) (Prijono et al., 1997). Furthermore, crude extracts of Melia volkensii have been shown to inhibit larval growth of Pseudaletia unipuncta (Haworth, 1809) (Lepidoptera: Noctuidae) (Akhtar \& Isman, 2004).

Therefore, the knowledge of how plant extracts act on oviposition and feeding can be an important tool in IPM for reducing the population of these insects before economic damage occurs. Consequently, this study serves as a basis for future studies on P. xylostella that aim to reduce the applications of synthetic inputs and the damage caused by this pest without promoting the selection of resistant individuals.

\section{Acknowledgements}

The authors would like to thank the Foundation to Support to Development of Education, Science and Technology of Mato Grosso do Sul State (FUNDECT); Brazilian National Research Council (CNPq)-Process: 304302/2015-5; Coordination of Improvement of Higher Level (CAPES) and Dra. Zefa Valdivina Pereira the identification of species. The SPQS is CNPq research productivity fellows.

\section{References}

Abbasipour, H., Mahmoudvand, M., Rastegar, F., \& Basij, M. (2010). Insecticidal activity of Peganum harmala seed extract against the diamondback moth, Plutella xylostella. Bulletin of Insectology, 63(2), 259-263.

Akhtar, Y., \& Isman, M. B. (2004). Comparative growth inhibitory and antifeedant effects of plant extracts and pure allelochemicals on four phytophagous insect species. Journal of Applied Entomology, 128(1), 32-38. https://doi.org/10.1046/j.1439-0418.2003.00806.x

Amoabeng, B. W., Gurrb, G. M., Gitau, C. W., \& Stevenson, P. C. (2014). Cost: Benefit analysis of botanical insecticide use in cabbage: Implications for smallholder farmers in developing countries. Crop Protection, 57, 71-76. https://doi.org/10.1016/j.cropro.2013.11.019

Ang, G. C. K., Zalucki, M. P., \& Furlong, M. (2016). Temporal changes in olfactory and oviposition responses of the diamondback moth to herbivore-induced host plants. Entomologia Experimentalis et Applicata, 160(1), 28-39. https://doi.org/10.1111/eea.12458

Aragão, F. A. S. de, Feitosa, F. A. A., Moraes, C. A. P., \& Correa, M. C. M. (2008). Sistema de produção de repolho com mulching e manta Agrotêxtil. Horticultura Brasileira, 26, 40-46.

Barros, R., Thuler, R. T., \& Pereira, F. F. (2012). Técnica de criação de Plutella xylostella (L., 1758) (Lepidoptera: Yponomeutidae). In D. Pratissoli (Ed.), Técnicas de criação de pragas de importância agrícola, em dietas naturais (1st ed., pp. 65-84). Vitória: Edufes.

Basukriadi, A., \& Wilkins, R. M. (2014). Oviposition deterrent activities of Pachyrhizus erosus seed extract and other natural products on Plutella xylostella (Lepidoptera: Plutellidae). Journal of Insect Science, 14(1), 1-5. https://doi.org/10.1093/jisesa/ieu106

Boiça Júnior, A. L., Janini, J. C., Souza, B. H. S., \& Rodrigues, N. E. L. (2013). Efeito de cultivares de repolho e doses de extrato aquoso de nim na alimentação e biologia de Plutella xylostella (Linnaeus) (Lepidoptera: Plutellidae). Bioscience Journal, 29(1), 22-31.

Camaroti, J. R. S. L., Almeida, W. A., Belmonte, B. R., De Oliveira, A. P. S., Lima, T. A., Ferreira, M. R. A., Napoleão, T. H. (2018). Sitophilus zeamais adults have survival and nutrition affected by Schinus terebinthifolius leaf extract and its lectin (SteLL). Industrial Crops and Products, 116, 81-89. https://doi.org/10.1016/j.indcrop.2018.02.065

Castillo, L., González-Coloma, A., González, A., Díaz, M., Santos, E., Alonso-Paz, E., Bassagoda, M. J., \& Rossini, C. (2009). Screening of Uruguayan plants for deterrent activity against insects. Industrial Crops and Products, 29(1), 235. https://doi.org/10.1016/j.indcrop.2008.05.004

Charleston, D. S., Gols, R., Hordijk, K. A., Kfir, R., Vet, L. E. M., \& Dicke, M. (2006). Impact of botanical pesticides derived from Melia azedarach and Azadirachta indica plants on the emission of volatiles that attract parasitoids of the diamondback moth to cabbage plants. Journal of Chemical Ecology, 32(2), 325-349. https://doi.org/10.1007/s10886-005-9004-9 
Chen, C. C., Chang, S. J., Hou, R. F., \& Cheng, L. I. (1996). Deterrent effect of the chinaberry extract on oviposition of the diamondback moth, Plutella xylostella (L.) (Lep. Yponomeutidae). Journal of Applied Entomology, 120(1-5), 165-169. https://doi.org/10.1111/j.1439-0418.1996.tb01585.x

Chirinos, R., Rogez, H., Campos, D., Pedreschi, R., \& Larondelle, Y. (2007). Optimization of extraction conditions of antioxidant phenolic compounds from mashua (Tropaeolum tuberosum Ruíz and Pavón) tubers. Separation and Purification Technology, 55(2), 217-225. https://doi.org/10.1016/j.seppur.2006. 12.005

Coelho, M. B., Marangoni, S., \& Macedo, M. L. (2007). Insecticidal action of Annona coriacea lectin against the flour moth Anagasta kuehniella and the rice moth Corcyra cephalonica (Lepidoptera: Pyralidae). Comparative Biochemistry and Physiology-Part C: Toxicology Pharmacology, 146(3), 406-14. https://doi.org/10.1016/j.cbpc.2007.05.001

Couto, I. F. S., Fuchs, M. L., Pereira, F. F., Mauad, M., Scalon, S. P. Q., Dresch, D. M., \& Mussury, R. M. (2016). Feeding preference of Plutella xylostella for leaves treated with plant extracts. Anais da Academia Brasileira de Ciências, 88(3), 1781-1789. https://doi.org/10.1590/0001-3765201620150236

Dayan, F. E., Cantrell, C., \& Duke, S. (2009). Natural product in crop protection. Bioorganic \& Medicinal Chemistry, 17(12), 4022-34. https://doi.org/10.1016/j.bmc.2009.01.046

Dover, J. W. (1985). The responses of some Lepidoptera to labiate herb and white clover extracts. Entomologia Experimentalis et Applicata, 39(2), 177-182. https://doi.org/10.1111/j.1570-7458.1985.tb03560.x

Egigu, M. C., Ibrahim, M. A., Yahya, A., \& Holopanen, J. K. (2010). Yeheb (Cordeauxia edulis) extract deters feeding and oviposition of Plutella and attracts its natural enemy. BioControl, 55(5), 613-624. https://doi.org/10.1007/s10526-010-9287-9

Feng, X., Jiang, H., Zhang, Y., He, W., \& Zhang, L. (2012). Insecticidal activities of ethanol extracts from thirty Chinese medicinal plants against Spodoptera exigua (Lepidoptera: Noctuidae). Journal of Medicinal Plants Research, 6(7), 1263-1267. https://doi.org/10.5897/JMPR11.1324

Feng, B., Qian, K., \& Du, Y. J. (2017). Floral Volatiles from Vigna unguiculata Are Olfactory and Gustatory Stimulants for Oviposition by the Bean Pod Borer Moth Maruca vitrata. Insects, 8(2), 60 . https://doi.org/10.3390/insects8020060

Fernandes, F. F., Leles, R. N., Silva, I. G., \& Freitas, E. P. S. (2007). Larvicidal potential of Sapindus saponaria (Sapindaceae) against Rhipicephalus sanguineus (Latreille, 1806) (Acari: Ixodidae). Arquivo Brasileiro de Medicina Veterinária e Zootecnia, 59(1), 145-149.

Freitas, A. F., Pereira, F. F., Formagio, A. S. N., Lucchetta, J. T., Vieira, M. C., \& Mussury, R. M. (2014). Effects of methanolic extracts of Annona species on the development and reproduction of Spodoptera frugiperda (J. E. Smith) (Lepidoptera: Noctuidae). Neotropical Entomology, 43(5), 446-452. https://doi.org/10.1007/ s13744-014-0225-x

Gross, J., \& Ligges, U. (2012). Nortest: Tests for normality (Version 1.0-2). R Package.

Heredia-Vieira, S. C., Simonet, A. M., Vilegas, W., \& Macías, F. A. (2015). Unusual C,O-Fused Glycosylapigenins from Serjania marginata Leaves. Journal of Natural Products, 78(1), 77-84. https://doi.org/10.1021/np500715x

Hermawan, W., Tsukuda, R., Nakajima, S., Fujisaki, K., \& Nakasuji, F. (1998). Oviposition deterrent activity of andrographolide against the diamondback moth (DBM), Plutella xylostella (Lepidoptera: Yponomeutidae). Applied Entomology and Zoology, 33(2), 239-241. https://doi.org/10.1303/aez.33.239

Isman, M. B. (1994). Botanical insecticides and antifeedants: New sources and perspectives. Pesticide Research Journal, 6, 11-19. Retrieved from http://www.spsindia.org.in/images/files/3.Isman.pdf

Johann, S., Sá, N. P., Lima, L. A. R. S., Cisalpino, P. S., Cota, B. B., Alves, T. M., Siqueira, E. P., \& Zani, C. L. (2010). Antifungal activity of schinol and a new biphenyl compound isolated from Schinus terebinthifolius against the pathogenic fungus Paracoccidioides brasiliensis. Annals of Clinical Microbiology and Antimicrobials, 9(30), 1-6. https://doi.org/10.1186/1476-0711-9-30

Khaliq, A., Attique, M. N. R., \& Sayyed, A. H. (2007). Evidence for resistance to pyrethroids and organophosphates in Plutella xylostella (Lepidoptera: Plutellidae) from Pakistan. Bulletin of Entomological Research, 97(2), 191-200. https://doi.org/10.1017/S0007485307004877 
Kodjo, T. A., Gbenonchi, M., Sadate, A., Komi, A., Yaovi, G., Dieudonne, M., \& Komla, S. (2011). Bio-insecticidal effects of plant extracts and oil emulsions of Ricinus communis L. (Malpighiales: Euphorbiaceae) on the diamondback, Plutella xylostella L. (Lepidoptera: Plutellidae) under laboratory and semi-field conditions. Journal of Applied Biosciences, 43, 2899-2914.

Kogan, M., \& Goeden, R. D. (1970). The host-plant range of Lema trilineata daturaphila (Coleoptera: Chrysomelidae). Annals of the Entomological Society of America, 63, 1175-1180. https://oi.org/10.1093/ aesa/63.4.1175

Koul, O. (2012) Plant Biodiversity as a Resource for Natural Products for Insect Pest Management. In G. M. Gurr, S. D. Wratten, W. E. Snyder, \& D. M. Y. Read (Eds.), Biodiversity and Insect Pests: Key Issues for Sustainable Management (pp. 85-105). John Wiley \& Sons, Ltd, Chichester, UK.

Koul, O. (2008). Phytochemicals and insect control: An antifeedant approach. Critical Reviews in Plant Sciences, 27(1), 1-24. https://doi.org/10.1080/07352680802053908

Koul, O. (2005). Insect Antifeedants (p. 1024). GRG Press, Boca Raton, Florida.

Krinski, D., Massaroli, A., \& Machado, M. (2014). Potencial inseticida de plantas da família Annonaceae. Revista Brasileira de Fruticultura, 36(1), 225-242. https://doi.org/10.1590/S0100-29452014000500027

Leatemia, J. A., \& Isman, M. B. (2004). Insecticidal activity of crude seed extracts of Annona spp., Lansium domesticum and Sandoricum koetjape against Lepidopteran larvae. Phytoparasitica, 32(1), 30-37.

Lestari, M. S., Himawan, T., Latif Abadi, A., \& Retnowati, R. (2015). Bioactivity crude extracts of Piper methysticum forst. F (piperaceae) against Plutella xylostella L. (Lepidoptera: Plutellidae). Journal of Chemical and Pharmaceutical Research, 7(5), 568-577.

Li, Z., Zalucki, M. P., Yonow, T., Kriticos, D., Bao, H., Chen, H., Hu, Z., Feng, X., \& Furlong, M. (2016). Population dynamics and management of diamondback moth (Plutella xylostella) in China: The relative contributions of climate, natural enemies and cropping patterns. Bulletin of Entomological Research, 106(2), 197-214. https://doi.org/10.1017/S0007485315001017.1

Medeiros, C. A. M., \& Boiça Júnior, A. L. (2005). Efeito da aplicação de extratos aquosos em couve na alimentação de lagartas de Ascia monuste orseis. Bragantia, 64(4), 633-641. https://doi.org/10.1590/S0006 $-87052005000400013$

Medeiros, C. A. M., Boiça Junior, A. L., \& Torres, A. L. (2005). Efeito de extratos aquosos de plantas na oviposicao da trada das cruciferas, em couve. Bragantia, 64(2), 227-232. https://doi.org/10.1590/S000687052005000200009

Mello, M. O., \& Silva-Filho, M. C. (2002). Plant-insect interactions: An evolutionary arms race between two distinct defense mechanisms. Brazilian Journal of Plant Physiology, 14(2), 71-81. https://oi.org/10.1590/ S1677-04202002000200001

Menezes, E. L. A. (2005). Inseticidas botânicos: Seus princípios ativos, modo de ação e uso agrícola (p. 58). Seropédica, Rio de Janeiro: Embrapa Agrobiologia.

Mohan, M., \& Gujar, G.T. (2003). Local variation in susceptibility of the diamondback moth Plutella xylostella (Linnaeus) to insecticides and role of detoxification enzymes. Crop Protection, 22(3), 495-504. https://doi.org/10.1016/S0261-2194(02)00201-6

Mordue, A. J., \& Blackwell, A. (1993). Azadirachtin: An update. Journal of Insect Physiology, 39(11), $903-924$. https://doi.org/10.1016/0022-1910(93)90001-8

Negi, P., Rawat, B. S., \& Negi, D. S. (2016). Antifeedant Constituents from Leucaena leucocephala. Journal of Applied Pharmaceutical Science, 6(12), 028-031. https://doi.org/10.7324/JAPS.2016.601204

Neto Bandeira, G., Augusto Gomes da Camara, C., Martins de Moraes, M., Barros, R., Muhammad, S., \& Akhtar, Y. (2013). Insecticidal activity of Muntingia calabura extracts against larvae and pupae of diamondback, Plutella xylostella (Lepidoptera, Plutellidae). Journal of King Saud University-Science, 25(1), 83-89. https://doi.org/10.1016/j.jksus.2012.08.002

Patil, S., Singh, R., \& Kalidhar, S. B. (2003). Effect of methanolic extract and its fractions of karanj (Pongamia pinnata) seeds on oviposition and egg hatching of Plutella xylostella (Lepidoptera: Yponomeutidae). Entomologia Generalis, 27(1), 025-033. https://doi.org/10.1127/entom.gen/27/2004/25 
Pavela, R. (2004). Insecticidal activity of certain medicinal plants. Fitoterapia, 75(7-8), 745-749. https://doi.org/ 10.1016/j.fitote.2004.08.005

Peres, L. L. S., Sobreiro, A. I., Couto, I. F. S., Silva, R. M., Pereira, F. F., Heredia-Vieira, S. C., Mussury, R. M. (2017). Chemical Compounds and Bioactivity of Aqueous Extracts of Alibertia spp. in the Control of Plutella xylostella L. (Lepidoptera: Plutellidae). Insects, 8(4), E125. https://doi.org/10.3390/insects8040125

Périco, L. L., Heredia-Vieira, S. C., Beserra, F. P., Dos Santos, R. C., Weiss, M. B., Resende, F. A., ... Hiruma-Lima, C. A. (2015). Does the gastroprotective action of a medicinal plant ensure healing effects? An integrative study of the biological effects of Serjania marginata Casar. (Sapindaceae) in rats. Journal of Ethnopharmacology, 172(22), 312-324. https://doi.org/10.1016/j.jep.2015.06.025

Prakash, A., \& Rao, J. (1997). Botanical pesticides in agriculture (p. 461, 1sd ed.). CRC Press Inc., Baton Rouge, Florida.

Prijono, D., Gani, M. S., \& Syahputra, E. (1997). Insecticidal activity of annonaceous seed extracts against Crocidolomia binotalis Zeller (Lepidoptera: Pyralidae). Buletin Hama dan Penyakit Tumbuhan, 9(1), 1-6.

Procópio, T. F., Fernandes, K. M., Pontual, E. V., Ximenes, R. M., De Oliveira, A. R. C., Souza, C. S., Napoleão, T. H. (2015). Schinus terebinthifolius Leaf Extract Causes Midgut Damage, Interfering with Survival and Development of Aedes aegypti Larvae. PLoS ONE, 10, e0126612. https://doi.org/10.1371/ journal.pone. 0126612

Qiu, Y. T., Van Loon, J., \& Roessingh, P. (1998). Chemoreception of oviposition deterring terpenoids in the diamondback moth Plutella xylostella. Entomologia Experimentalis Et Applicata, 87(2), 143-156. https://doi.org/10.1046/j.1570-7458.1998.00316.x

Ribeiro, L., Zanardi, O., Gonçalves, G. L., Ansante, T., Yamamoto, P., \& Vendramim, J. D. (2017). Toxicity of an Annonin-Based Commercial Bioinsecticide against Three Primary Pest Species of Stored Products. Neotropical Entomology, 47(1), 145-151. https://doi.org/10.1007/s13744-017-0510-6

Sapindal, E., Ong, K. H., \& King, P. J. H. (2017). Efficacy of Azadirachta excelsa vinegar against Plutella xylostella. International Journal of Pest Management, 64(1), 39-44. https://doi.org/10.1080/09670874. 2017.1293866

Sarfraz, M., \& Keddie, B. A. (2005). Conserving the efficacy of insecticides against Plutella xylostella (Lepidoptera: Plutellidae). Journal of Applied Entomology, 129, 149-157. https://doi.org/10.1111/j.1439 $-0418.2005 .00930 . \mathrm{x}$

Saxena, R. C., Dixit, O. P., \& Sukumaran, P. (1992). Laboratory assessment of indigenous plant extracts for antijuvenile hormone activity in Culex quinquefasciatus. Indian Journal of Medical Research, 95, 204-206. Retrieved from https://www.ncbi.nlm.nih.gov/pubmed/1398811

Schenkel, E. P., Gosmann, G., Athayde, M. L., Simões, C. M., Schenkel, E. P., Gosmann, G., Petrovick, P. R. (2001). Farmacognosia: da planta ao medicamento (3rd ed., pp. 597-619). Porto Alegre.

Schneider, C. A., Rasband, W. S., \& Eliceiri, K. W. (2012). NIH Image to ImageJ: 25 years of image analysis. Nature Methods, 9, 671-675. https://doi.org/10.1038/nmeth.2089

Shaalan, E. A., Canyon, D., Younes, M. W., Abdel-Wahab, H., \& Mansour, A. H. (2005) A review of botanical phytochemicals with mosquitocidal potential. Environment International, 31(8), 1149-66. https://doi.org/ 10.1016/j.envint.2005.03.003

Shin-Foon, C., \& Yu-Tong, Q. (1993). Experiments on the application of botanical insecticides for the control of diamondback moth in South China. Journal of Applied Entomology, 116, 479-486. https://doi.org/10.1111/ j.1439-0418.1993.tb01224.x

Silva, F. A. S., \& Azevedo, C. A. V. (2016). The Assistat Software Version 7.7 and its use in the analysis of experimental data. African Journal of Agricultural Research, 11, 3733-3740. https://doi.org/10.5897/ AJAR2016.11522

Simpson, S. J., \& Simpson, C. L. (1990). The Mechanisms of Nutritional Compensation by Phytophagous Insects. Insect-Plant Interation, 2, 111-160.

Tabashnik, B. E. (1985). Deterrence of diamondback moth (Lepidoptera: Plutellidae) oviposition by plant compounds. Environmental Entomology, 14, 575-578. https://doi.org/10.1093/ee/14.5.575

Taiz, L., \& Zeiger, E. (2003). Fisiologia vegetal (5th ed., p. 954). Porto Alegre: Artmed. 
Talukder, F. A., \& Howse, P. E. (1994). Laboratory evaluation of toxic repellent properties of the pithraj tree, Aphanamixis polystachya Wall \& Parker, against Sitophilus oryzae (L.). International Journal of Pest Management, 40, 274-279. https://doi.org/10.1080/09670879409371897

Torres, A. L., Boiça Júnior, A. L., Medeiros, C. A. M., \& Barros, R. (2006). Effect of aqueous extracts of Azadirachta indica (A. Juss), Melia azedarach (L.) and Aspidosperma pyrifolium (Mart.) on the development and oviposition of Plutella xylostella (L.) (Lepidoptera: Plutellidae). Bragantia, 65(3), 447-457. https://doi.org/10.1590/S0006-87052006000300011

Vickers, R. A., Furlong, M. J., White, A., \& Pell, J. K. (2004). Initiation of fungal epizootics in diamondback moth populations within a large field cage: proof of concept of autodissemination. Entomologia Experimentalis et Applicata, 111, 7-17. https://doi.org/10.1111/j.0013-8703.2004.00140.x

Wheeler, D. A., \& Isman, M. B. (2001). Antifeedant and toxic activity of Trichilia americana extract against the larvae of Spodoptera litura. Entomologia Experimentalis et Applicata, 98(1), 9-16.

Wheeler, D. A, Isman, M. B., Sanchez-Vindas, P. E., \& Arnason, J. T. (2001). Screening of Costa Rican Trichilia species for biological activity against the larvae of Spodoptera litura (Lepidoptera: Noctuidae). Biochemical Systematics and Ecology, 29(4), 347-358. https://doi.org/10.1016/S0305-1978(00)00070-3

Yuan, L., Xue, M., Liu, L., \& Wang, H. (2006). Toxicity and oviposition-deterrence of Vitex negundo extracts to Plutella xylostella. The Journal of Applied Ecology, 17(4), 695-698.

Zafra-Polo, M. C., Gonzáles, M. C., Estornell, E., Sahpaz, S., \& Cortés, D. (1996). Acetogenins from Annonaceae, inhibitor of mitocondrial complex I. Phytochemistry, 42(2), 253-271. https://oi.org/10.1016/ 0031-9422(95)00836-5

Zhang, M. X., Ling, B., Chen, S. Y., Liang, G. W., \& Pang, X. F. (2004). Repellent and oviposition deterrent activities of the essential oil from Mikania micrantha and its compounds on Plutella xylostella. Insect Science, 11, 37-45. https://doi.org/10.1111/j.1744-7917.2004.tb00178.x

\section{Copyrights}

Copyright for this article is retained by the author(s), with first publication rights granted to the journal.

This is an open-access article distributed under the terms and conditions of the Creative Commons Attribution license (http://creativecommons.org/licenses/by/4.0/). 